\title{
2. Political Life Writing in Papua New Guinea
}

\author{
What, Who, Why?
}

\author{
Jonathan Ritchie
}

Political life writing in Papua New Guinea (PNG) raises themes and issues which resonate across much of Melanesia. Like elsewhere, the individual lived life provides a convenient prism through which to view the larger patterns and processes of society. In this chapter, I write about the pleasure of researching and writing the biography of one of Papua New Guinea's independence leaders and a 'founding father' of the nation, the late Sir Ebia Olewale, and reflect on how my book relates to other efforts. ${ }^{1}$ I worked on this project between 2009 and 2012 .

This most rewarding exercise has led me to think about the context in which it was undertaken. When I started researching for the book I was under the impression that, by and large, it would be one of the very few works of biography or autobiography about or by Papua New Guineans who played a part in PNG's journey to independence. It would join the small group that includes, among a handful of other works, Michael Somare's Sana, Maori Kiki's Ten Thousand Years in a Lifetime, and Josephine Abaijah's A Thousand Coloured Dreams.

As the project developed, however, I began to wonder more and more about this. Why was it that so little had been written, either by or about Papua New Guineans and their almost unique experience - of moving, to borrow Kiki's oftenrepeated title, 'ten thousand years in a lifetime'? This apparent dearth is even more pronounced when compared with the flourishing genre of writing about PNG by Australians, as Hank Nelson explored in his contribution to the 'Telling Pacific Lives' symposium at The Australian National University: Nelson listed 207 books published between 1980 and 2008 'primarily by or about Australians who went to Papua New Guinea'. ${ }^{2}$ Was it that, after the efflorescence of the late 1960s and early 1970s, the idea of a Papua New Guinean historiography writing by or about Papua New Guineans rather than Australians in PNG - had withered, a victim like so much else of the turning off of the money tap? Was it that, as Stephen Pokawin told the 2008 Waigani Seminar at the University of

\footnotetext{
1 J. Ritchie, Ebia Olewale: a Life of Service (Port Moresby 2012).

2 H. Nelson, 'Lives Told: Australians in Papua and New Guinea', in B. Lal and V. Luker (eds), Telling Pacific Lives: Prisms of Process (Canberra 2008), 264.
} 
Papua New Guinea (UPNG), 'Papua New Guinea is a speaking culture', in which the written word takes second place to the primacy of orally handed-down tradition? Why was it?

In fact, at that same Waigani Seminar I became aware of the possibility that there might be more to PNG life writing than the 'usual suspects' of Somare, Kiki, Abaijah and others. Specifically, the workshop on PNG writing and publishing that preceded the seminar ('Buk2Book', organised by Dr John Evans of the UPNG Press and Bookshop) revealed that there was a significant number of writers toiling away, telling the stories of their villages, their people, and their own lives - publishing, if at all, via the medium of the A4 sheet of paper, the printer, and the ring binder. Since then, the growth of internet use and social networking has provided an even more available avenue for publishing life stories.

So, when the opportunity arose to contribute to a symposium on political life writing in the Pacific, I thought that it might be helpful to dig into this a little more, to try to find out what the real situation might be. What has been, or is being, written in the way of life stories by or about Papua New Guineans? What is the status of political - or any - biography and autobiography in that country? Are Sana, Ten Thousand Years, and A Thousand Coloured Dreams more or less it, or is an entire undercurrent of self-published writing going on in offices, schools, and missions? In what follows, I hope to be able to address these questions, and attempt some analysis of not only the question of what has been written, but also why it has been written. As part of this survey, I will subject my own experience with the biography of one Papua New Guinean, Ebia Olewale, to a closer analysis: what motivated me to take on this task, what I learned during the exercise, and what I hope the outcomes will be.

Before beginning to examine what life writing has been written in PNG, by or about Papua New Guineans, it might be helpful to devote a few sentences to the question of how much of Papua New Guinean life writing can be called 'political'. By this I mean the extent to which biography or autobiography in PNG can be considered political, or whether it is life writing of another variety - set for example in the context of a sporting or religious life. This distinction need not delay us much, however. On reflection, I am persuaded by the assessment made by Philip Selth at a symposium on political biography held at The Australian National University in 2005. 'Trying to define a political biography', Selth concluded, 'is a sterile debate'. ${ }^{3}$ I concur; it is very difficult and, by and large, unnecessary to try to separate the political from any other filter that one might attempt to place on a life. To borrow a catchcry popular in late

3 P. Selth, 'Political Biographies and Administrative Memoirs: Some Concluding Comments', in T. Arklay et al. (eds), Australian Political Lives: Chronicling Political Careers and Administrative Histories (Canberra 2006), 103, available online at press.anu.edu.au/anzsog/auspol/html/frames.php. 
1960s second-wave feminism, in PNG 'the personal is political' . ${ }^{4}$ Any account of a life must encompass the social context in which that life has been lived: after all, man is by nature a political animal, as Aristotle famously expressed it. ${ }^{5}$ Especially in a new state like PNG, meaning and influence can be attached to the life experiences of any member of the community who - through their lives being recorded in some way - automatically becomes part of the politics of the community or nation. Furthermore, as Tracey Arklay has expressed it, political biography:

... provides one set of tools by which to explore history and events from within the temporal and historical context of one life. It allows exploration of the events of history - from a micro perspective - looking at them through the eyes of someone who lived, breathed and was part of that history. ${ }^{6}$

Returning to the question of what has been, or is being, written, I consider that using this broader definition is the best way to look at PNG political life writing. While the most well-known works by players like Somare, Kiki or Abaijah are clearly books of political biography, it is possible to see a political aspect to many others. I hope that this will become obvious in the necessarily brief overview that follows.

The most immediate conclusion is that, despite my original perception, PNG biography and autobiography is - while not exactly well - far from moribund. There have been many books of life writing and a large number of shorter pieces that together form a body of literature about the lives of men and women in PNG. While many were produced in the brief period of efflorescence from the late 1960s to the early 1980s, they continue to be written to this day.

This paper will focus on books published and will not devote a great deal of space to the collection of shorter biographical works, apart from one vital mention: the outstanding record of the lives of many hundreds of Papua New Guineans in the journal Oral History published since 1972 by the Institute of PNG Studies. The articles in Oral History, collected by students of UPNG and others, often with the aid of small cassette recorders, are indelible reminders of the power of life story telling and really deserve special attention by themselves.

\footnotetext{
4 C. Hanisch, 'The Personal is Political', Women of the World, Unite! Writings by Carol Hanisch (1969) available online at www.carolhanisch.org/CHwritings/PIP.html.

5 Aristotle, Politics, 1.1253a, available online at www.perseus.tufts.edu/hopper/text?doc=Perseus:abo:tlg, 0086,035:1:1253a.

6 T. Arklay, 'Political Biography: Its Contribution to Political Science', in T. Arklay et al. (eds), Australian Political Lives: Chronicling Political Careers and Administrative Histories (Canberra 2006), 21.
} 
The collections open a window into a time in which the world for many Papua New Guineans had begun to change, and they deserve fuller exposition in their own right as records of lives lived very much in a political context.

Outside of the pages of Oral History, there are four chief locations for this shorter type of life story writing. In each case, the purpose for recording and retelling carries a different emphasis.

The first of these are the biographical accounts provided in official and semiofficial publications, mainly with the purpose of assisting the program of political education in late colonial and early independent PNG. The most prominent of these are three publications about the structure and membership of PNG's legislative body, the House of Assembly, during the last years of the colonial era. Included here are brief descriptive profiles of every Member of the House from 1964 to 1976, set out in as objective and dispassionate a manner as the (unknown) writers were able to achieve. Typically these would list sketchy details of birth, education, and employment, and where applicable some information concerning the subject's parliamentary record. There are 182 individual records of elected Members of the House of Assembly from 1964 to 1976, including nine who won their seats in each of the first three consecutive elections in 1964, 1968 and 1972: Tei Abal, Kaibelt Diria, Sinake Giregire, John Guise, Paul Lapun, Pita Lus, Ronald Neville, Pangial Momei, and Matthias Toliman. ${ }^{7}$ Other short descriptions of a biographical nature are in the Australian Government publication Australian External Territories, from 1968 to 1971. As well, they appear in the files of the Australian administration and other overseas governments; these, however, were usually not intended for public consumption. ${ }^{8}$

Moving away from the officially recorded biographical portraits, there have been a number of short articles in journals such as New Guinea and Australia, The Pacific and South-east Asia, The Journal of the Papua and New Guinea Society, and Yagl-Ambu; usually these encompassed biographical sketches of prominent Papua New Guineans such as Josephine Abaijah, John Momis, Julius Chan, and Kondom Agaundo. In some cases, they were compiled by other Papua New Guineans: one example is the detailed and informed exposition of the 1974 leader of the United Party, Tei Abal, by Utula Samana, then a student of UPNG. ${ }^{9}$

\footnotetext{
7 The Members of the House of Assembly 1964, Port Moresby: Department of Information and Extension Services, (1964); 1968-1972 Members of the Second House of Assembly: Territory of Papua and New Guinea, Port Moresby: Department of Information and Extension Services, (1968); 1972-1976 Members of the Third House of Assembly: Papua New Guinea, Port Moresby: Department of Information and Extension Services, (1972).

8 See, for example, the British Government file 'Leading personalities in Papua New Guinea 1978', National Archives of the United Kingdom, Commonwealth Office, Far East and Pacific Department and Foreign and Commonwealth Office, South West Pacific Department: Registered Files (H and FW Series), FCO 24/2489.

9 U. Samana, 'Tei Abal', Yagl-Ambu, 3: 1 (1974), 219-29.
} 
A third avenue for publishing short biographical profiles of Papua New Guinean subjects comes in the form of specific anthologies of life stories. Two prominent examples of this are Shaping the Future: Papua New Guinea Personalities and Niugini Lives, both published in 1974 and both with an overtly political message. Shaping the Future, edited by the German missionary and lecturer Friedrich Steinbauer, comprises mostly autobiographical portraits by a diverse group of Papua New Guineans active in public life during the early 1970s; subjects range from leading political personalities such as Michael Somare, Paulias Matane and Oala Oala-Rarua to less well-known figures whom Steinbauer considered to represent the emerging character of the new nation. As he explained:

I have chosen some less famous people to make clear that the development of a country depends not only on Government decisions at high levels, but also on the many trends and influences which flow from ordinary men and women in their everyday life. ${ }^{10}$

Prepared at the same time, and similarly selective in its choice of subjects, but with an even more pronounced sense of the alliance between literature and political consciousness, is Niugini Lives, the collection of mainly autobiographical sketches edited by Ulli Beier. As Beier explained in the introduction to the collection, interest in autobiography arose in response to the 'flood of mission memoirs, kiap [patrol officer] tales, anthropological treatises and sensational coffee table books'. He continued: 'It was clearly felt that by talking about their own lives, Papua New Guineans could be authentic and authoritative in destroying the intricate maze of myth woven by white writers' ${ }^{11}$ The accounts in Niugini Lives, with one exception (by Ligeremaluoga Osea, explored below), were included because of the light they shed on a people discovering their potential after the preceding decades of repressive and paternalist colonialism.

Last in this brief overview of the shorter pieces of life story writing are the biographical entries included in two general reference collections: Ann Turner's Historical Dictionary of Papua New Guinea and the Australian Dictionary of Biography. Turner's monumental work includes brief descriptions of 63 Papua New Guineans, ranging from the Highlands leader Ningi Kama (c. 1893-1963) to John Pundari (1967- ), the Minister for Environment and Conservation in the PNG National Government. It is an essential reference for anyone interested in PNG, not only in its biographical entries but also in its scope of the many factors which have contributed to the composition and character of the contemporary nation. ${ }^{12}$

10 F. Steinbauer, Shaping the Future: Papua New Guinea Personalities (Madang 1975), ix-x.

11 U. Beier, (ed.) Niugini Lives (Milton 1974), 3.

12 A. Turner, Historical Dictionary of Papua New Guinea (Lanham 1994). 
Finally in this overview of the shorter pieces of political life writing on or by Papua New Guineans are the - admittedly few - entries in the Australian Dictionary of Biography. As Hank Nelson observed, the criteria for inclusion in the Dictionary are somewhat blurred for Papua New Guineans, with their complicated historical relationship with Australia (Papuans as 'less than citizens of Australia', and New Guineans as Australian protected persons). ${ }^{13}$ Nevertheless, there are 15 Papua New Guineans included in the online version of the Dictionary (up to 2012): Kondom Agaundo, Paulus Arek, Francis Hagai, Tommy Kabu, Gabriel Ehava Karava, Oala Oala-Rarua, Ahiua Ova, Pita Simogun, Simoi, Sumsuma, Matthias Toliman, Peter ToRot, Louis Vangeke, Alice Wedega, and Yali. ${ }^{14}$

Turning to published books, most observers have concluded that PNG's biographical output has been moderate, if not meagre. At the 'Telling Pacific Lives' symposium, the anthropologist Michael Goddard began his discussion of Motu-Koita personal narratives by asserting that 'since the late colonial period, there have been a significant number of publications which could be roughly classified as Melanesian autobiography' ${ }^{15}$ He includes in this number Michael Somare's Sana, Maori Kiki's Ten Thousand Years in a Lifetime, Josephine Abaijah's A Thousand Coloured Dreams, the autobiographies of two Western Highlands Big Men, Ongka and Ru, and Virginia Watson's Anyan's Story. ${ }^{16}$ While each of these books is without doubt significant, if this represents all there is by way of PNG life writing then there is a problem. The situation, however, is substantially more positive than would perhaps appear.

In fact, over the 80 years between 1932 and 2012, 37 biographical or autobiographical books have been published by, or about, Papua New Guineans. Sixteen have been autobiographies and 21 biographies. Eighteen have been written either completely or primarily by Papua New Guineans - not surprisingly, this includes all the autobiographies but also two of the biographies. It is probable that many more have been written, and either self-published or produced in such a way that they are not easily sourced outside their immediate locality.

13 Nelson, 'Lives Told', 254.

14 These are all available in the Australian Dictionary of Biography online, Canberra: National Centre for Biography, The Australian National University, available online at adb.anu.edu.au.

15 M. Goddard, 'From "My Story" to "The Story of Myself" - Colonial Transformations of Personal Narratives among the Motu-Koita of Papua New Guinea', in B. Lal and V. Luker (eds), Telling Pacific Lives: Prisms of Process (Canberra 2008), 35.

16 J. Abaijah and E. Wright (eds), A Thousand Coloured Dreams: The Story of a Young Girl Growing Up in Papua (Mount Waverley 1991); A.M. Kiki, Kiki: Ten Thousand Years in a Lifetime; a New Guinea Autobiography (Melbourne 1968); Ongka, Ongka: a Self-account by a New Guinea Big Man (London 1979); Ru, Ru, Biography of a Western Highlander, (Boroko 1993); M. Somare, Sana: an Autobiography of Michael Somare (Port Moresby 1975); and V. Watson, Anyan's story: a New Guinea Woman in Two Worlds (Seattle 1997). 
Beginning in 1932, the earliest attempt at either biography or autobiography is that of Ligeremaluoga Osea. Ligeremaluoga, born in the 1890s in New Ireland, was an early convert to Christianity who became a teacher in the 1920s. Using his baptismal name of Hosea or Osea, he became an instructor at George Brown College at Watnabara in New Britain, marrying Anasain Pisig whose death in 1930 left him depressed and desolate. On the advice of the Australian missionary Ella Collins, who gave him the only help he received from a white person being a slip of paper with half-a-dozen headings written on it as a guide', ${ }^{17}$ Ligeremaluoga wrote his life story until that time; it was published in 1932 as Erstwhile Savage. The Papua New Guinean writer and academic Steven Winduo, at least, considers this book to be 'by all accounts the first written account by a South Pacific Islander'. ${ }^{18}$

In later life, Ligeremaluoga continued to be an elder, becoming second in charge of George Brown College in 1946. Retiring in 1961, he 'left a large footprint in the sand for his children and others to follow' in Winduo's assessment, and indeed his son David Linge became the first Papua New Guinean to gain a doctorate in biological sciences. In 2013 he was a member of the School of Medicine and Health Sciences at UPNG.

That this pioneering writer has not received the plaudits he should have, is in no small part due to the criticism of his writing by the late Ulli Beier. Beier, who sadly passed away in 2011, was a hugely influential figure in both Nigeria and PNG, considered by many to be 'the father of modern literature' in both nations. ${ }^{19}$ On his arrival at UPNG in 1967, after a groundbreaking period in Nigeria, Beier set about the task of introducing creative writing to a group of Papua New Guineans: '... some of the brightest and certainly the most politically conscious students ... aware that they were the first generation of Papuans and New Guineans who could talk back to the white man' ${ }^{20}$

Many of those first students, anti-colonialists all, went on to prominence in post-independence PNG. In relation to Erstwhile Savage, however, Beier was unimpressed. A man of strong ideas and judgement, he was dismissive of Ligeremaluoga's book which, while he included an excerpt from it in his Niugini Lives, he nonetheless considered 'a book without literary merit', ${ }^{21}$ written by a man who, as 'the first Christian convert in his village ... was therefore

17 E. Collins, 'Preface', in L Osea (ed.), An Account of The Life of Ligeremaluoga (Osea) (Melbourne 1932), 6. 18 S. Winduo, 'The first PNG Writer: Hosea Linge', Steven's Window, available online at stevenswindow. blogspot.com.au/2012/03/first-png-writer-hosea-linge.html.

19 W.H. Chong, 'Death of a Giant (blak soul white skin: Ulli Beier)', Crikey, 5 April 2011, available online at blogs.crikey.com.au/culture-mulcher/2011/04/05/death-of-a-giant-ulli-beier/.

20 U. Beier, Decolonising the Mind: the impact of the university on culture and identity in Papua New Guinea, 1971-74 (Canberra 2005), 56.

$21 —$ 'Literature in New Guinea', The Hudson Review, 24: 1 (1971), 119. 
anxious to prove himself a good disciple'.$^{22}$ While remaining deeply critical, Beier permitted a part of the book to be included with the other contributions to Niugini Lives, not for its literary (or indeed political) merit but as 'an interesting historical document' that sheds light on the 'objectionable' paternalism of the missionaries. ${ }^{23}$

But does Ligeremaluoga warrant such condemnation? The fact that Beier dismissed his book shows much about the context of the times in which the criticism was made, when authentic literature was considered the handmaiden of political consciousness, and reading between the lines about indigenous responses to colonialism was not practised as often as it has been more recently. But Ligeremaluoga was himself writing in such a context, and a more nuanced understanding of his work and his place in the small pool that is Papua New Guinean historiography is required. As Steven Winduo points out, Ligeremaluoga was a significant and influential leader in his church and society until his death in 1975 (he lived long enough to read Beier's criticism of his groundbreaking work). He was a role model for many young Papua New Guineans who, one way or another, would need some way of successfully managing the transition to nationhood. As such, and as the writer of what was certainly PNG's first autobiography (if not the entire South Pacific's), he deserves his place in this brief exposition.

At the other end of the 80 years, two books of biography were published in 2012. One was the biography of the late Sir Ebia Olewale, one of the founders of Papua New Guinean independence and an influential figure in the shaping of the modern PNG nation, of which more will be said later.

The other is Nameless Warriors: the Ben Moide Story by the Papua New Guinean diplomat Lahui Ako. Both books were published by UPNG Press, and although - as its author - I am able to discuss the Olewale book in some detail, unfortunately Ako's book has remained elusive for the non-Papua New Guinean resident; and the following brief exploration relies on a presentation by Ako in Port Moresby in November 2012, and a slightly less recent (August 2012) review by the Papua New Guinean journalist, Malum Nalu. ${ }^{24}$

Ben Moide was not a politician - at least not in the sense that is often understood. In 1940, aged 16, Moide ran away from home to join the Papuan Infantry Battalion, with whom he fought alongside his Papuan and New Guinean comrades throughout the Kokoda campaign and until 1945. Ako's biography addresses both his war service and the challenges that faced him and other Papuans and

22 'Introduction', in U. Beier (ed.), Niugini Lives, 1.

23 'Literature in New Guinea', in U. Beier (ed.), Niugini Lives, 119.

24 M. Nalu, 'New book tells of the nameless warriors of $\mathrm{PNG}^{\prime}$, Malum Nalu (blog), available online at malumnalu.blogspot.com.au/2012/08/new-book-tells-story-of-nameless.html. 
New Guineans who returned to paternalism and racism following the war as they tried to make a living for their families. Moide's experience as a soldier and instructor led the Australian administration to entrust him with the job of driver for senior public servants, including the Administrator, J.K. Murray, and the Director of Health and Assistant Administrator, Dr John Gunther. Nevertheless, and despite his position of apparent powerlessness compared with Olewale, Moide has been a person of some influence in his modelling of behaviour and community leadership, including his representational role internationally that reminds us - or educates us - about the vital part played by Papuans and New Guineans in the war. ${ }^{25}$

Ebia Olewale was very much a politician; or at least he believed in the importance of public service and his own role in attempting to make positive differences in the lives of his fellow Papua New Guineans. He related how, when he was a boy at school in Daru in PNG's Western District, the teacher scolded the class for misbehaviour, telling them that nothing would come of them. Olewale's response was life changing:

I thought about those words and I said 'well, I think one day I'm going to really work hard and show him that I'm going to do something for my own people'. So that's where I really set my mind on politics. ${ }^{26}$

The vow that he made that day took him to further education at the influential Sogeri High School (at the time PNG's only government secondary school) and Port Moresby Teachers' College, where his interest in anti-colonialism grew, fed by the ham-fisted policies of the Australian Administration on public service pay issues and poor conditions for local (that is, Papua New Guinean) officers. Stimulated by the late night discussions with other like-minded young Papua New Guineans, and informed by the rapidly unfolding decolonisation process in Africa - in particular as expounded by people like Kenya's Tom Mboya Olewale became a key member of the small pro-independence group that led eventually to the founding of the nationalist Pangu Pati.

After being elected to the House of Assembly, he was a Minister in the Somare government from 1972 to 1980, in which capacity he drove initiatives in education, small business, and justice, as well as helping to shape the new nation's foreign policy as Minister for Foreign Affairs, following Maori Kiki in that role. After electoral loss in 1982, he spent more than a decade searching

25 A recent example being his interview on ABC Local Radio on 20 April 2012, available online at blogs.abc. net.au/queensland/2012/04/ben-moide-and-the-fuzzy-wuzzy-angels.html.

26 Ritchie, Ebia Olewale: a Life of Service, 33. 
for ways to further his political involvement, before re-entering the arena as an 'elder statesman' in the 1990s, continuing into this century as a board member of the PNG Sustainable Development Program Ltd. Olewale died, aged 68, in 2009.

The opportunity to research and write Olewale's biography is something that I have valued enormously. Funding for the project was provided by the Sustainable Development Program, the company set up in 2002 following the withdrawal of the transnational mining giant BHP Billiton. The project was intended to form part of Olewale's legacy, the other main parts of which were his strong interest in economic regeneration for Daru and the development of the mining town of Tabubil to ensure continued commercial activity following the eventual retirement of the Ok Tedi mine which it serviced. The project has inherited much from the approach taken by Ulli Beier four decades earlier in that it has facilitated seeing the process of colonial demise and new nation formation, not from the perspective of the expatriate specialist but through the eyes of someone who was there and whose life was influenced - profoundly - by the process, and who in turn was able to influence it. The main problem - that it is still me, an expatriate and not a Papua New Guinean writer who has taken the project on - is partially countered by my own connection with PNG (I was born there, with both my parents and grandparents having lived and worked there since the 1920s) and by the fact that Olewale had taken the trouble to record some of his early life experiences and so, in a sense, had influenced the way his story - his legacy - would be told.

Despite this problem, however, I am proud to have been associated with the project - however flawed it has been. Olewale lived through times that were more momentous than possibly any that had gone before, with the most profound effects on all inhabitants of the islands we now call Papua New Guinea. His experiences - and those of his contemporaries - need to be recorded for the benefit of the many generations of Papua New Guineans to come, and it has been a privilege to be part of this project. I hope that there will be many more such biographies.

Among the accounts of these three key figures - Ligeremaluoga and Olewale and Moide - lie some 34 other books that can be categorised as political life writing. With the broad definition in mind of what political life writing entails, there are a few ways in which these can be further classified.

To begin with, there are the books that are openly and avowedly political in scope and purpose. Leading the way is Sir Michael Somare and his autobiography Sana, curiously perhaps published in 1975 when he was still a young man (he turned 40 the following year). Sir Maori Kiki's book Kiki: Ten Thousand Years in a Lifetime (published in 1968 while the author was 37 years old) has a similar purpose. As Beier - with whom he collaborated closely on the book - 
has noted, at a time when 'Papua New Guineans felt they were being reduced to the status of guinea pigs ... Kiki showed them that they could recreate their own image' ${ }^{27} \mathrm{He}$ and others place Kiki's book at the forefront of the renaissance (or should it be the 'naissance') of Papua New Guinean literature.

Beier was also influential in the preparation of Somare's autobiography, Sana, a book with an avowedly political purpose (he worked with interviews taped with Somare and - jointly with Tony Voutas - edited the outcome). ${ }^{28}$ Indeed both books were intricately caught up in the politics of nationalism and anti-colonialism, and it is significant that they appeared when Ulli Beier's influence through his work at UPNG and, later, the Institute of PNG Studies was at its zenith. They appeared amid the explosion of indigenous Papua New Guinean creativity that characterised this period, including in the visual arts (Akis, Kauage and others), theatre (Arthur Jawodimbari, Kumalau Tawali), poetry (the Papua Pocket Poets series), and fiction (Vincent Eri's The Crocodile being the leading example of this genre).

While Somare's book and Kiki's are the most prominent examples of the political autobiography genre, others deserve a mention in this discussion of books of life writing in PNG. One of these is Dame Josephine Abaijah's A Thousand Coloured Dreams: The Story of a Young Girl Growing Up in Papua, which she wrote with her advisor and friend Dr Eric Wright. Although ostensibly a work of fiction she insisted that it was 'based on my life but ... all of the characters in this work are fictitious' - A Thousand Coloured Dreams nonetheless can be considered in this survey of political life writing in PNG. Abaijah, as the public face of Papua Besena (the movement agitating for separate development of Papua from New Guinea), was a significant feature of the PNG landscape in the 1970s and $A$ Thousand Coloured Dreams, although published some time afterwards, recorded her encounters with colonialism and her own political journey. In the words of Jeffrey R.J. Dickens' introduction to the book, Abaijah 'has devoted her life to the People and the country she loves and in so doing has provided the inspiration the National women of Papua New Guinea needed' ${ }^{29}$

Other books have been written by Papua New Guineans who also had prominent roles in public affairs spanning the late colonial and early independence era. The former Governor-General, Sir Paulias Matane, has been quite prolific in more recent times, and among his 27 books there are two in particular that can be counted in this overview of political biography: My Childhood in New Guinea (1972) and To Serve With Love (1992). Born in 1931 in a village in

\footnotetext{
27 Beier, 'Introduction', 3.

28 T. Lipp, The Hunter Thinks the Monkey is Wise, But He Has His Own Logic: A Bibliography of Writings by Ulli Beier, Obotunde Ijimere \& Co., (rev. edn), Clin D'Oeil, (Bayreuth 1986), available online at www.thorolflipp.de/publications/documents/TheHunterthinksthemonkeyisnotwise.pdf.

29 R.J. Dickens, 'Tribute to Josephine', in J. Abaijah and E. Wright (eds), A Thousand Coloured Dreams, iii.
} 
East New Britain, Matane's life has taken him through the ranks of teaching and other public service roles, culminating in ambassadorial postings in the United States, Mexico, Canada and the United Nations, and, finally, as Governor-General from 2004 to 2010. His two books of autobiography (leaving aside the accounts of travels) tell the story of, as he described it in My Childhood in New Guinea, a journey which 'began with the stone age and has entered the space age' ${ }^{30}$

Two autobiographies by leading Papua New Guinean women can also be considered in this survey: Dame Alice Wedega's Listen My Country (1981), and Dame Carol Kidu's A Remarkable Journey (2002). Wedega's life story spanned a large part of the twentieth century, from her birth in 1905 to her death at the age of 82 in 1987; she witnessed many of PNG's most important moments, from missionising to war, to the growing movement for self-determination and independence. The book emphasises her experiences as a Christian and as a woman; and indeed the political purpose she had in mind in writing it was laid out in its concluding chapter:

The real need of Papua New Guinea is for unity. Unity in families, unity between tribes and different areas of the country. If women see this need and care for everyone they work with, they can show others how this can be done. Meeting the needs of people is the aim we must have. ${ }^{31}$

Kidu's career in PNG politics formally ended with her retirement at the 2012 elections, although she remains an enormously significant figure in PNG public affairs. In A Remarkable Journey, she chose to write about her journey from Brisbane schoolgirl to that of a Member of Papua New Guinea's National Parliament. ${ }^{32}$ It is, as Regis Stella describes, 'a narrative about her mental and physical struggles, pains and perseverance to adjust and adapt into a culturally different society' ${ }^{33}$ Although born an Australian, Kidu features in this survey because of her choice to identify with the nation of her husband, the late Sir Buri Kidu, and as a Motuan woman. The first part of her autobiography was published as A Remarkable Journey. She is now contemplating a second part which would detail her life in politics including her years as a Minister and Opposition Leader (see Kidu, Chapter 10).

All of these books reflect the excitement and optimism of the nation, a people in transition to a future that was unknowable but which would, without doubt, be drastically different to what had gone before. In the words of John Momis at the time of independence, '... we really did not know where we were going.

30 P. Matane, My Childhood in New Guinea (Melbourne 1972), 112.

31 A. Wedega, Listen, My Country (Sydney 1981), 107.

32 C. Kidu, A Remarkable Journey (Sydney 2002).

33 R. Stella, 'A Remarkable Journey (review)', The Contemporary Pacific, 15: 1(2003), 222. 
We were like Abraham, called to a destination which he didn't know.' ${ }^{34}$ As Ted Wolfers wrote in the introduction to Matane's second volume of autobiography, '... the experiences depicted ... are, in their essentials, those of an entire generation of Papua New Guinean pioneers ${ }^{\prime 35}$ and the stories that each of these books tells are important reminders of the great hopes and expectations of that era.

Before moving on from books that are clearly political in their scope - dealing with subjects who have been intricately connected with the political landscape of PNG - there are two 'honourable mentions' that should be included here. They are not counted as books as such because they have not been published, but are certainly book-like in their scope and structure. These are the doctoral dissertations by Basil Shaw on Michael Somare, submitted in 1991, and Lisabeth Lee Ryder on Iambakey Okuk, submitted in 1992. Both are detailed and scholarly examinations of their subject's lives, in Ryder's case from a close personal relationship with her subject, while Shaw's was more archive-based.

Shaw approached his subject by looking at concepts of leadership in traditional Papua New Guinean societies, and how these played out in the contemporary political world; in particular, how Somare and his colleagues were confronted with challenges arising from this process. Although limited by the timeframe - concluding his examination of Somare in 1985 when he left office - and the lack of interview material, Shaw's dissertation effectively addressed its central question of 'whether the style of political leadership in PNG has expressed itself in a different set of behaviours from what is traditional among leaders in the Westminster Parliament and its associated executive form of government' ${ }^{36}$

Ryder, on the other hand, chose to examine the life of the Chimbu leader Sir Iambakey Palma Okuk, who came close to becoming Prime Minister before his untimely death in 1986. An anthropologist, Ryder explained how her dissertation's aim was 'both to supplement the interpretations of Papua New Guinean history, and to contribute to the investigation and evaluation of life histories as an anthropological methodology' $\cdot{ }^{37}$ Her recognition that too often in Western literary accounts, 'Papua New Guineans ... are dealt with as a

\footnotetext{
34 J. Momis, 'Transcript of Discussion by Constitution-Makers, Port Moresby, 28 March 1996', in A.J. Regan, O. Jessep and E.L. Kwa (eds), Twenty Years of the Papua New Guinea Constitution (Sydney 2001), 357. 35 T. Wolfers, 'Introduction', in P. Matane (ed.), To Serve with Love (Mount Waverley 1992), viii.

36 B. Shaw, Somare: a Political Biography of the First Prime Minister of Papua New Guinea (Nathan 1991), 545.

37 L.L. Ryder, Iambakey Okuk: Interpretations of a Lifetime of Change in Papua New Guinea, PhD thesis (Los Angeles 1992), ix.
} 
mass phenomena' led her to the conclusion that 'Papua New Guinea's past was populated with extraordinary people, people with names'.$^{38}$ This is a conclusion with which this paper is in complete agreement.

Many books articulate the same story of progression from 'the stone age to the space age', as Matane described it, or 'ten thousand years in a lifetime', in Kiki's words, whether the book has been written by a Papua New Guinean or by an expatriate. Sometimes a duality, a sense of existence in two worlds that conveys a similar meaning, is also expressed. Thus, we have Elin Johnston's biography of the Anglican Bishop George Ambo, subtitled Man of Two Worlds: someone who exists in the traditional and the modern worlds at the same time. Johnston describes him as 'a transitional man, [whose] life stretches from the end of the Stone Age, through the Colonial Period and into the modern Technological Era'. ${ }^{39}$ Other examples are Mama Kuma, Deborah Carlyon's biography of her grandmother, Kuma Kelage. One Woman, Two Cultures, its subtitle, conveys the duality of Kelage's world between her Sina people and those of the man she married, Malcolm Warrick. ${ }^{40}$ Audrey McCollum's account of her friend Pirip Kuru, Two Women, Two Worlds: Friendship Swept by Winds of Change, ${ }^{41}$ similarly addresses this duality, marvelling at the paradox where 'a feminist activist from an ancient culture that included the subjugation of women could preserve that endangered culture and organize women to achieve greater equality and power' ${ }^{42}$

Life story telling is an approach deployed by anthropology as well as history and political science, as Geoffrey M. White has noted: 'the study of life history' he wrote in 2000, 'continues to be put forward as an effective, even innovative way to approach issues of agency, meaning, and representation', an outcome he ascribes to the fact that 'life histories and associated issues of individual agency have in theoretical terms been a marginal and largely unexamined element of a discipline otherwise preoccupied with analyzing the collective' ${ }^{43}$ Andrew Strathern has explained this in a more specific reference to his relationship with the Western Highlands Big Men Ongka and Ru. The point of using life histories in anthropological research, he argues, is 'to relate local ideas about personhood and individuality, in a broad sense, to local cases of life experience, especially when these cases are narrated by the people themselves' ${ }^{44}$

\footnotetext{
38 Ibid., 4.

39 E.E. Johnston, Bishop George: Man of Two Worlds, self-published (2003), x.

40 D. Carlyon, Mama Kuma: One Woman, Two Cultures (St Lucia 2002).

41 A. McCollum, Two Women, Two Worlds: Friendship Swept by Winds of Change (New Hampshire 1999).

42 'Two Women Two Worlds', Whole Earth, Winter (2002), 80.

43 G.M. White, 'Afterword: Lives and Histories', in P.J. Stewart and A. Strathern (eds), Identity Work: Constructing Pacific Lives (Pittsburgh 2000), 172.

44 A. Strathern, 'A twist of the rope', in V. Keck (ed.), Common Worlds and Single Lives: Constituting Knowledge in Pacific Societies (Oxford 1998), 119.
} 
So here is another contributor to the corpus of autobiographical and biographical literature of PNG and one, moreover, that is again overtly political, if on a subnational scale.

Three final mentions of books remain to be added to this list (although much has been passed over - as the list of published works of a biographical nature at the end of this chapter indicates).

The first is Amirah Inglis's Karo: the Life and Fate of a Papuan, which retells the story of a Kerema man, Karo Araua, whose life began in the village and spanned the arbitrary divide of colonial Port Moresby. Like Chief Roi Mata in Vanuatu, Araua has acquired a legendary and mythic reality, not least through the songs Inglis recorded, including on how his fame grew:

The fame of his daring deed spread to his Auavavu land,

The story of his reckless exploit reached his Mukosore place;

It spread to his Auavavu-Mukosore land.

His Savoripi clansmen's ears heard the fame of his daring deed,

His Savoripi clanswomen's ears learned the story of his reckless exploit, The fame of his daring deed. ${ }^{45}$

As Inglis noted:

Even though Papuans are now Papua New Guineans and the government is no longer a colonial one, they still sing and enjoy to hear the story of 'white foreigners' brought down or at least made to sit up and take notice of a Papuan man. ${ }^{46}$

Without a doubt, Inglis has written a biography of a political figure who lived and died many years before the idea of PNG as a nation began.

The second is perhaps something that may seem out of place in a survey of political life writing: the sporting autobiography, a genre often passed over by academic observers but usually enormously popular with the general public. The autobiography that is included here belongs to a prominent player and coach of rugby league, the sport of which most Papua New Guineans are passionate devotees. Stanley Gene's Daydream Believer - edited, if not exactly ghostwritten, by Stuart Wilkin - tells of his journey from a squatter settlement in Goroka to rugby league stardom in the United Kingdom with Hull Kingston Rovers, and several Test caps with PNG's national rugby league team, the Kumuls, whom he then moved on to coach following his eventual retirement as

45 A. Inglis, Karo: the Life and Fate of a Papuan (Canberra 1982), 125.

46 Ibid., 120. 
a player. ${ }^{47}$ Gene's book, with its strong message of self-betterment and service, is a political work in its promotion of an activist and change-oriented outlook, particularly among PNG's mostly disenfranchised young people. In a country as rugby league mad as PNG, the power of a book such as Daydream Believer to influence political outcomes is evident.

Final in this partial exposition of the books of political life writing in PNG are the many short books written by Eric Johns, intended for schools and published by Pearson Education. Johns' work has been largely unreported in academic or literary circles. This is a great shame as he has researched meticulously and the books he has produced provide a valuable aid for young Papua New Guineans to understand their own history.

So, to conclude. Far from being moribund, there are signs of healthy life in Papua New Guinean biographical historiography, especially if a wider interpretation is taken of what constitutes a publication. There are, however, too few works of serious biography of contemporary political or otherwise national leaders. What is needed is to move away from the trope that is perhaps the most obvious and easily adopted - that of the progressive journey from the village to the nation, the stone age to the space age, ten thousand years in a lifetime - to a more nuanced and sophisticated treatment of the impact modernity has had on PNG's people. Studies of how the nation's leaders manipulated and were affected by the arrival of a global marketplace of commodities and ideas are important avenues to increasing our understanding of the ways of articulation, action, and response. While biography has sometimes been disparaged as being 'not quite kosher', and the standard of scholarship which might even be considered 'suspect', ${ }^{48}$ it has the ability to 'provide students of politics with another perspective of how power is shared, how leaders are made not born, and how circumstances can catapult ordinary people into extraordinary situations' ${ }^{49}$ In the context of PNG, these are all worthy aims.

47 S. Gene and S. Wilkin, Daydream Believer (Derbyshire 2007).

48 T. Arklay, J. Nethercote and J. Wanna, 'Preface', in T. Arklay et al. (eds), Australian Political Lives, xi.

49 Selth, ‘Political Biographies and Administrative Memoirs’, 101. 
Table 1: Biographical works about, or by, Papua New Guineans

\begin{tabular}{|c|c|c|c|c|}
\hline \multicolumn{5}{|c|}{ Published books } \\
\hline Subject & Title & Author(s) & Publisher & Date \\
\hline $\begin{array}{l}\text { Josephine } \\
\text { Abaijah }\end{array}$ & $\begin{array}{l}\text { A Thousand Coloured } \\
\text { Dreams }\end{array}$ & $\begin{array}{l}\text { Josephine Abaijah } \\
\text { and the late Dr } \\
\text { Eric Wright }\end{array}$ & Dellasta Pacific & 1991 \\
\hline Lahui Ako & $\begin{array}{l}\text { Upstream Through } \\
\text { Endless Sands of } \\
\text { Blessings }\end{array}$ & Lahui Ako & $\begin{array}{l}\text { CBS Publishers \& } \\
\text { Distributors }\end{array}$ & 2007 \\
\hline George Ambo & $\begin{array}{l}\text { Bishop George: Man of } \\
\text { Two Worlds }\end{array}$ & Elin Johnston & self-published & 2003 \\
\hline Anyan & $\begin{array}{l}\text { Anyan's Story: A New } \\
\text { Guinea Woman in Two } \\
\text { Worlds }\end{array}$ & $\begin{array}{l}\text { Virginia Drew } \\
\text { Watson }\end{array}$ & $\begin{array}{l}\text { University of } \\
\text { Washington Press }\end{array}$ & 1997 \\
\hline Karo Araua & $\begin{array}{l}\text { Karo: the Life and Fate } \\
\text { of a Papuan }\end{array}$ & Amirah Inglis & $\begin{array}{l}\text { Institute of } \\
\text { Papua New } \\
\text { Guinea Studies } \\
\text { in association } \\
\text { with Australian } \\
\text { National } \\
\text { University Press }\end{array}$ & 1982 \\
\hline Pipi Gari & Pipi Gari of Elevala & Eric Johns & $\begin{array}{l}\text { Pearson Education } \\
\text { Australia }\end{array}$ & 2003 \\
\hline Stanley Gene & Daydream Believer & $\begin{array}{l}\text { Stanley Gene with } \\
\text { Stuart Wilkin }\end{array}$ & TH Media & 2007 \\
\hline Kei Geno & $\begin{array}{l}\text { Beyond the Untrod } \\
\text { Road: Biography of } \\
\text { Major Kei Geno, the } \\
\text { First Papua New } \\
\text { Guinean Salvationist }\end{array}$ & $\begin{array}{l}\text { Ruth Raimo and } \\
\text { Anja Marie Bray }\end{array}$ & self-published & 2006 \\
\hline Golpak & $\begin{array}{l}\text { Sir Simogun Pita and } \\
\text { Paramount Luluai Golpak }\end{array}$ & Eric Johns & $\begin{array}{l}\text { Pearson Education } \\
\text { Australia }\end{array}$ & 2004 \\
\hline Ravu Henao & Ravu Henao of Papua & Marcus L Loane & S. John Bacon & 1945 \\
\hline Rose Kekedo & Dame Rose Kekedo & Eric Johns & $\begin{array}{l}\text { Pearson Education } \\
\text { Australia }\end{array}$ & 2002 \\
\hline Kuma Kelage & $\begin{array}{l}\text { Mama Kuma: One } \\
\text { Woman, Two Cultures }\end{array}$ & Deborah Carlyon & $\begin{array}{l}\text { University of } \\
\text { Queensland Press }\end{array}$ & 2002 \\
\hline $\begin{array}{l}\text { Limbie Kelly } \\
\text { Kelegai }\end{array}$ & $\begin{array}{l}\text { Through the Eye of } \\
\text { the Storm: Every Step, } \\
\text { Every Heartbeat, in } \\
\text { God's Grace }\end{array}$ & $\begin{array}{l}\text { Limbie Kelly } \\
\text { Kelegai }\end{array}$ & BookPal & 2009 \\
\hline Carol Kidu & A Remarkable Journey & Carol Kidu & Longman & 2002 \\
\hline Carol Kidu & Lady Carol Kidu & Eric Johns & $\begin{array}{l}\text { Pearson Education } \\
\text { Australia }\end{array}$ & 2005 \\
\hline $\begin{array}{l}\text { Albert Maori } \\
\text { Kiki }\end{array}$ & $\begin{array}{l}\text { Kiki: Ten Thousand } \\
\text { Years in a Lifetime: } \\
\text { A New Guinea } \\
\text { Autobiography }\end{array}$ & Albert Maori Kiki & Cheshire & 1968 \\
\hline
\end{tabular}


Political Life Writing in the Pacific

\begin{tabular}{|c|c|c|c|c|}
\hline \multicolumn{5}{|c|}{ Published books } \\
\hline Subject & Title & Author(s) & Publisher & Date \\
\hline Pirip Kuru & $\begin{array}{l}\text { Two Women Two } \\
\text { Worlds: Friendship } \\
\text { Swept by Winds of } \\
\text { Change }\end{array}$ & $\begin{array}{l}\text { Audrey T } \\
\text { McCollum }\end{array}$ & Hillwinds Press & 1999 \\
\hline $\begin{array}{l}\text { Osea } \\
\text { Ligeremaluoga }\end{array}$ & $\begin{array}{l}\text { An Account of the Life } \\
\text { of Ligermaluoga (Osea): } \\
\text { An Autobiography }\end{array}$ & $\begin{array}{l}\text { Osea } \\
\text { Ligeremaluoga } \\
\text { (trans. Ella Collins) }\end{array}$ & FW Cheshire & 1932 \\
\hline $\begin{array}{l}\text { Hosea } \\
\text { Ligeremaluoga }\end{array}$ & $\begin{array}{l}\text { An Offering Fit for a } \\
\text { King: the Life and Work } \\
\text { of the Rev. Hosea Linge }\end{array}$ & $\begin{array}{l}\text { Hosea Linge } \\
\text { (trans. Neville } \\
\text { Threlfall) } \\
\end{array}$ & Toksave Buk & 1978 \\
\hline $\begin{array}{l}\text { Hosea } \\
\text { Ligeremaluoga }\end{array}$ & Ligeremaluoga of Kono & Eric Johns & $\begin{array}{l}\text { Pearson Education } \\
\text { Australia }\end{array}$ & 2002 \\
\hline Maino & $\begin{array}{l}\text { Maino of Moatta and } \\
\text { the Explorers of the Fly } \\
\text { River }\end{array}$ & Eric Johns & $\begin{array}{l}\text { Pearson Education } \\
\text { Australia }\end{array}$ & 2002 \\
\hline Paulias Matane & $\begin{array}{l}\text { My Childhood in New } \\
\text { Guinea }\end{array}$ & Paulias Matane & $\begin{array}{l}\text { Oxford University } \\
\text { Press }\end{array}$ & 1972 \\
\hline Paulias Matane & To Serve with Love & Paulias Matane & Dellasta Pacific & 1992 \\
\hline Ben Moide & $\begin{array}{l}\text { Nameless Warriors: The } \\
\text { Ben Moide Story }\end{array}$ & Lahui Ako & UPNG Press & 2012 \\
\hline Ebia Olewale & $\begin{array}{l}\text { Ebia Olewale: a Life of } \\
\text { Service }\end{array}$ & Jonathan Ritchie & UPNG Press & 2012 \\
\hline Ongka & $\begin{array}{l}\text { Ongka: a Self-account } \\
\text { by a New Guinea Big } \\
\text { Man }\end{array}$ & $\begin{array}{l}\text { Ongka with } \\
\text { Andrew Strathern }\end{array}$ & Duckworth & 1979 \\
\hline Ongka & $\begin{array}{l}\text { Collaborations and } \\
\text { Conflicts: a Leader } \\
\text { Through Time }\end{array}$ & $\begin{array}{l}\text { Ongka with } \\
\text { Andrew Strathern } \\
\text { and Pamela J } \\
\text { Stewart }\end{array}$ & Thomson & 2006 \\
\hline Madi Roua & $\begin{array}{l}\text { The Past Years: the } \\
\text { Autobiography of Madi } \\
\text { Roua }\end{array}$ & Madi Roua & self-published & 2005 \\
\hline $\mathrm{Ru}$ & $\begin{array}{l}\text { Ru: Biography of a } \\
\text { Western Highlander }\end{array}$ & $\begin{array}{l}\text { Ru, translated by } \\
\text { Andrew Strathern }\end{array}$ & $\begin{array}{l}\text { National Research } \\
\text { Institute }\end{array}$ & 1993 \\
\hline Pita Simogun & $\begin{array}{l}\text { Sir Simogun Pita and } \\
\text { Paramount Luluai } \\
\text { Golpak }\end{array}$ & Eric Johns & $\begin{array}{l}\text { Pearson Education } \\
\text { Australia }\end{array}$ & 2004 \\
\hline $\begin{array}{l}\text { Michael } \\
\text { Somare }\end{array}$ & Sana & Michael Somare & $\begin{array}{l}\text { The Jacaranda } \\
\text { Press }\end{array}$ & 1975 \\
\hline Peter ToRot & $\begin{array}{l}\text { The Life of Peter ToRot } \\
\text { Catechist Church } \\
\text { Leader and Martyr }\end{array}$ & $\begin{array}{l}\text { Caspar G. } \\
\text { Tovaninara }\end{array}$ & $\begin{array}{l}\text { Missionaries of } \\
\text { the Sacred Heart }\end{array}$ & n.d. \\
\hline
\end{tabular}




\begin{tabular}{|c|c|c|c|c|}
\hline \multicolumn{5}{|c|}{ Published books } \\
\hline Subject & Title & Author(s) & Publisher & Date \\
\hline $\begin{array}{l}\text { Benedict To } \\
\text { Varpin }\end{array}$ & $\begin{array}{l}\text { Tubuan and Tabernacle, } \\
\text { the Life Stories of } \\
\text { Two Priests of Papua } \\
\text { New Guinea: the Most } \\
\text { Reverened Benedict To } \\
\text { Varpin, CBE Archbishop } \\
\text { Emeritus: Reverend } \\
\text { Father Bernard Franke } \\
\text { MSC, CBE Missionary in } \\
\text { New Britain }\end{array}$ & Mary R Mennis & Lalong Enterprises & 2007 \\
\hline Tui & Tui of Gorendu & Eric Johns & $\begin{array}{l}\text { Pearson Education } \\
\text { Australia }\end{array}$ & 2003 \\
\hline Louis Vangeke & $\begin{array}{l}\text { Bishop Sir Louis } \\
\text { Vangeke }\end{array}$ & Eric Johns & $\begin{array}{l}\text { Pearson Education } \\
\text { Australia }\end{array}$ & 2002 \\
\hline Alice Wedega & Listen My Country & Alice Wedega & $\begin{array}{l}\text { Pacific } \\
\text { Publications }\end{array}$ & 1981 \\
\hline Alice Wedega & Dame Alice Wedega & Eric Johns & $\begin{array}{l}\text { Pearson Education } \\
\text { Australia }\end{array}$ & 2002 \\
\hline \multicolumn{5}{|l|}{ Theses } \\
\hline $\begin{array}{l}\text { Michael } \\
\text { Somare }\end{array}$ & $\begin{array}{l}\text { Somare: A Political } \\
\text { Biography of the First } \\
\text { Prime Minister of Papua } \\
\text { New Guinea }\end{array}$ & Basil Shaw & Griffith University & 1991 \\
\hline lambakey Okuk & $\begin{array}{l}\text { lambakey Okuk: } \\
\text { Interpretations of a } \\
\text { Lifetime of Change in } \\
\text { Papua New Guinea }\end{array}$ & Lisabeth Lee Ryder & $\begin{array}{l}\text { University of } \\
\text { California, Los } \\
\text { Angeles }\end{array}$ & 1992 \\
\hline
\end{tabular}

Source: Author's compilation. 
This text is taken from Political Life Writing in the Pacific:

Reflections on Practice, edited by Jack Corbett and Brij V. Lal, published 2015 by ANU Press, The Australian National University, Canberra, Australia. 